\title{
Assessment as a veritable tool for effective teaching and learning
}

\author{
Odo John Ogar \\ Department of Biology, College of Education, Oju, Benue State, Nigeria
}

\begin{abstract}
This paper examines assessment as a tool for effective teaching and learning. It revealed the concept of teaching and learning in lined with its improvement through the use of assessment. The concept of assessment and its various forms were $\mathrm{x}$-rayed as a means of assessing both the teaching and learning. The author thereafter examines the problems of operating assessment in the schools to include among others, the difficulty of incorporating assessment scores to final examinations, lack of qualified teachers and large classes. The author further shield light on the implications of assessment to teaching and learning with the main idea that, where assessment is implemented effectively, it raises standard of achievement across the board. Finally, the author recommends among others that stakeholders in education and the external examination bodies should brain storm on the possible ways to incorporate assessment scores of students to final examination scores, government and private organizations should assist in training and re-training of teachers to effectively handle students' assessment and teachers were called upon to find way of receiving better feedback from learners by improving on the quality of class room dialogue.
\end{abstract}

Keywords: effective teaching; effective learning; quality of class room dialogue

\section{INTRODUCTION}

Teaching is conceptualized as an active, constructive process in which the teacher assumes the role of a strategic planner, making decisions about the content and appropriate instructional strategies. (Oyetunde 2004). In other words, effective teaching is a deliberate and planned activity. It is purposeful (goal-oriented), coherent (structured), meaningful (bridges the gap between the known and unknown), and functional. All this implies that effective teaching consists in assisting students to acquire and use knowledge, and learn to think and solve problems.

Learning is viewed similarly as an active, constructive process that is contextual. That is, new knowledge is acquired in relation to the previous knowledge. This thinking about teaching and learning to be effective has implication for various instructional strategies like appropriate teaching methods, setting out achievable behavioural objectives, proper assessment and evaluation techniques. The thrust of this paper is on the use of assessment to enhance teaching and learning. It discussed the concept of assessment in wholesome and point out some problems in operating assessment in the Nigeria schools and finally, the implication of assessment for teaching and learning. 


\section{CONCEPT OF ASSESSMENT}

Assessment is no longer a new concept in the Nigeria educational system. It was introduced into Nigerian schools in the 1980s following the provision of the national policy on education that educational assessment and evaluation will be liberalized by basing them in a whole or in part on continues assessment of the progress of the individual (FGN, 1998), and so on. Assessment as a concept is the process of collecting information for decision making in education about students, curricular and programmes and educational policies. (Afemikhe 2007). In the words of Akem and Aduloju (2003), assessment is a mechanism where by the final grading of a student in the cognitive, affective and psychomotor domains account in the systematic way of his performance during a given period of schooling. The view the authors above hold reveals that the concept of assessment is broader than examination. It include exam as one of the measurement techniques used. These mean that assessment can be continuous and as such it provides a more comprehensive evaluation of the extent which the students have achieved the objectives of education compares to one -short exam that is administered in schools. In this paper, the term 'assessment' refers to all those activities undertaken by teachers and students themselves, which provide information to be used as feedback to modify the teaching and learning activities in which they are engaged.

\section{FORMS OF ASSESSMENT}

Though several forms of assessment exist, Wiliam (2006) outlined two broad forms namely the summative and formative assessment. The difference hitterto is based on the purpose, how the evidence gathered will be used and by whom.

\section{1. Formative Assessment}

Several views exist about formative assessment though with the same notions. Formative assessment according to Black and Wiliam (2009) is all those activities which teachers and learners use information about students' achievement to improve their achievements. Nicol, and Debra (2005), who emphasizes the role students can play in producing formative assessment state that formative assessment aids learning by generating feedback information that is of benefit to the students and teachers. They revealed that feedback on performance, in class or on assignments enables students to restructure their understanding/ skills and build more powerful ideas and capabilities.

The rational for formative assessment is to provide feedback for teachers to modify subsequent learning activities. This is in line with the notion of Ari (2010) who assert that the rational for formative assessment is to identify and remediate group or individual deficiencies and to move focus away from achieving grades and onto learning processes, in order to increase self efficacy and reduce negative importance of extrinsic motivation.

An example of formative assessment suffices to be: A science supervisor looks at the previous year's students test results to help plan teacher workshops during the summer vacation, to address areas of weakness in student's performance.

\section{2. Summative Assessment}

Summative assessment refers to the assessment of the learning and summarizes the development of learners at a particular time (Glickman, Gordon and Ross- Gordon 2009). This 
implies that after a period of work, example, a unit for two weeks, the learners sits for a test and then the teacher marks the test and assigns a score. The test aims to summarize learning up to that point. The test may also be used for diagnostic assessment to identify weakness and then build on that using formative assessment.

Glickman et al (2009), commenting on the rational of summative assessment revealed that it is a means to meet the school or district's needs for teacher accountability and looks to provide remediation for sub-standard performance and also provides ground for dismissal if necessary.

Summative assessment is characterized as assessment of learning and is contrasted with formative assessment which is assessment for learning. It provides information on the product's efficacy (its ability to do what it was designed to do). Glickman et al (2009) outlined some of the characteristics of summative assessment to include:

1) It is the procedure to assess or grade educator's level of learning in certain period of time.

2) It tends to use well defined evaluation design

3) It is positive, tending to stress what students can do rather than what they cannot.

From the above therefore, the assessment of teaching and learning can be viewed as two complementary and overlapping activities that aim to benefit both the quality of student learning and the professional development of the teacher. Assessing learning alone is not sufficient because the ultimate success of students is also dependent upon their motivation and commitment to learning.

Done in tandem, assessing teaching and learning can help teachers improve and refined their teaching practices and help improve students' learning and performance. This is also in agreement with the view of Afemikhe (2007) when he posits that assessment if appropriately implemented may enhance standard of education.

\section{PROBLEMS OF OPERATING ASSESSMENT}

Assessment has become an integral part of the national education system from primary to tertiary levels considering its importance in enhancing teaching and learning. Unfortunately its implementation has been criticized. (Osokoya and Odinko 2005). At the senior secondary school level, continuous assessment is expected to be incorporated into certification examination scores but there are concerns as to how this is effectively been done.

Other problems that mar the operation of continuous assessment as highlighted by Akem and Aduloju (2013) include lack of commitment by the teachers owing to their present condition of poor remuneration and delay in their salaries payment, and lack of qualified teachers to effectively handle students assessment in all the domains. Stressing on these, Akpan and Agbe (2009) asserted that most of the teachers handling assessment are known to lack essential skills due to the wrong way they are being trained. This wrong way of training results in the unacceptable instructional methods of assessment by teachers.

Again, problem of large classes, lack of fund, and shortage of staff have not been helpful in proper implementation of continuous assessment, which hitherto $\mathrm{h}$ rob - on effect in teaching and learning in the educational system. 


\section{IMPLICATIONS FOR TEACHING AND LEARNING}

1. Assessment is an essential part of effective teaching. Good teachers constantly, assess their pupils' learning. They recognize the need to understand what and how learners are thinking, and use this to enhance future learning. For formative assessment to be effective, teachers need to focus on how children are learning. They need to 'get inside' children's head to connect with their thinking and feelings.

2. Teaching and learning must be an interactive, collaborative process, where teachers can talk with pupils and raise open- ended questions in order to construct and share their understandings, a view which is consistent with the ideas of vygotsky (1978) on scaffolding which gives teachers a key role in extending children's understanding as it develops.

3. In line with learning, assessment increases the capacity to learn with self- motivation playing a crucial role. What motivates us and how other people can influence our self motivation is very complex. Assessment for learning therefore places emphasis on helping pupils to achieve success through their own efforts and using techniques that work for them. Being wrong, making mistakes and struggling to understand or to do something is necessary and formative part of learning. It can help young people to change their ideas about intelligence and understand how they can become smarter and better learners.

\section{CONCLUSION AND RECOMMENDATIONS}

This paper X- rays the concept of teaching and learning and relates it to assessment which is viewed as a tool for enhancing teaching and learning. The problems of operating assessment were highlighted which were capable of having a rob- on effects on the nation's educational system. Also it revealed the implication of effective assessment to teaching and learning. Thus where pupils are given better quality support and feedback and are encouraged to take more responsibility they learn more effectively.

In using assessment to improving teaching and learning which is the thesis of this paper, the following recommendations were made:

1. Stakeholders in education and the external examination bodies like West African Examination Council (WAEC) and National Examination Council (NECO) should brain storm on the possible way to incorporate continuous assessment scores to the external examination scores.

2. Teachers should be motivated by improve salary package and early payment to boost their morals towards improved performance of their duties.

3. Government should ensure regular training and re-training of teachers to effectively handle students assessment

4. Government and private organizations should assist in recruitment of qualified teachers to reduce the high students to teacher ratio inherent in the Nigerian schools, for effective teaching and learning.

5. The effective promotion of assessment for learning requires teachers to recognize that feedback is a two-way process. Teachers therefore not only need to find ways to give more effective feedback to learners, they should also find way of receiving better feedback from learners through improving on the quality of classroom dialogue, timely and focused feedback as well as making marks count in the students performance. 


\section{References}

[1] Afemikhe, O.A. (2007): Assessment and educational standard Improvement: Reflections from Nigeria. A paper presented at the $33^{\text {rd }}$ Annual Conference on the International Association for Educational Assessment held at Baku, Azebaijan (September, 16-21).

[2] Akem, J.A. and Agbe, N.N. (2000). Rudiments of Measurement and Evaluation in Education and psychology. Makurdi: the Return Press.

[3] Akem, J.A. and Aduloju, M.O. (2003). Principles of Measurement And Evaluation: Continuous Assessment and psychological testing in Education. Makurdi: Confidence Books limited.

[4] Ari, H. (2010). Dignostic and Formative Assessment: The Handbook of Educational linguistic. Oxford, UK: Black well pp 469-482.

[5] Black, P. J and Wiliam, D. (2009). Developing the theory of Formative Assessment. Educational Assessment, Evaluation and accountability, 21(11), 5-31.

[6] Federal Republic of Nigeria. (1998). National Policy of Education Yaba- Lagos: NERDC press.

[7] Glickman, C.D. Gordon, S. \& Ross-Gordon, I.M. (2009). Supervision and instructional Leadership: A developmental approach. Boston MA: Allyn and bacon.

[8] Nicol, D, Debra M.D. (2005). Rethinking Formative Assessment in HE: A theoretical model and seven principles of good feedback practice. Quality Assurance Agency for Higher Education 4(4), 6-10.

[9] Osokoya, M.M. and Odinko, M.N. (2005). The practice of continuous Assessment in primary school. In Emeke, A.E. and Ase, C.V. (eds). Evaluation in theory and practice (141-154) Ibadan: pen services.

[10] Oyetunde, T.O. (2004). Understanding Teaching and Learning process. In Andzayi, C.A., Mallum, Y.A. \& Oyetunde, T.O. (eds). The practice of teaching: perspective and strategies. Jos: LECAPS Publishers.

[11] Vygotsky, L.S. (1978). Mind in society: the development of higher psychology processes. Cambridge, MA: Harvard University press.

[12] William, D. (2006). Formative Assessment: Getting the focus right. Educational assessment. 11, 283-289.

[13] Borowski A., International Letters of Social and Humanistic Sciences 1 (2013) 14-18.

[14] Donovan A. McFarlane, International Letters of Social and Humanistic Sciences 4 (2013) 35-44.

[15] Borowski A., International Letters of Social and Humanistic Sciences 4 (2013) 70-74.

[16] Hussein Meihami, International Letters of Social and Humanistic Sciences 8 (2013) 24-33.

[17] Parkash Chandra Jena, Latif Ahmad, International Letters of Social and Humanistic Sciences 9 (2013) 1-10.

[18] Azuh Oluchi Jannet, Melody Ndidi Modebelu, International Letters of Social and Humanistic Sciences 2 (2014) 88-96. 
[19] Abdulrahaman W. Lawal, International Letters of Social and Humanistic Sciences 3 (2014) 53-59.

[20] M. N. Modebelu, F. K. Igwebuike, International Letters of Social and Humanistic Sciences 4 (2014) 40-48.

[21] Akor Isaiah Akem, Victor Tavershima Ukeli, International Letters of Social and Humanistic Sciences 4 (2014) 49-59.

[22] Nwachukwu Uche Emma, International Letters of Social and Humanistic Sciences 5 (2014) 1-12. 